\title{
Performance and ultrasound measurements of beef cattle fed diets based on whole corn or oats grains
}

\author{
Hugo M. Arelovich ${ }^{*}$, Rodrigo D. Bravo², Marcela F. Martínez², Pedro L. Forgue², \\ and Sergio O. Torquati ${ }^{2}$
}

\begin{abstract}
This study intended to contrast dietary effects of whole grain oats versus corn included in rations with moderate roughage content on animal performance, beef ultrasound measurements, rumen and blood parameters. Ten Aberdeen Angus steers $(203 \mathrm{~kg})$ in individual pens were fed twice daily on either whole oats (OD) or corn (CD) based diets. Measurements were: DM intake (DMI), average daily gain (ADG), feed to gain ratio (F/G); back fat (BF) and rib eye area (RA); blood parameters. Four cannulated steers were used to study rumen $\mathrm{pH}, \mathrm{NH}_{3}-\mathrm{N}$ and grain degradability. Rations dietary components were $55 \%$ grain, $30.1 \%$ barley straw, and $10.6 \%$ whole soybeans. Despite calculated higher ME supply $(\mathrm{P}=0.0887)$ no differences were found for DMI, ADG, or F/G. Metabolizable protein intake (19.4\%) was larger and degradable protein intake (43.3\%) smaller for $\mathrm{CD}$ compared with $\mathrm{OD}(\mathrm{P}<0.01)$. The growth rate $\left(\mathrm{cm}^{2} \mathrm{~d}^{-1}\right)$ for RA was $40 \%$ grater for OD, but larger $\mathrm{BF}$ deposition $(\mathrm{P}=0.0787)$ was found for $\mathrm{CD}$. Blood $\mathrm{Mg}$ was higher for OD $(\mathrm{p}=0.0564)$, nevertheless other blood parameters remained unaffected. Rumen $\mathrm{pH}$ and $\mathrm{NH}_{3}-\mathrm{N}$ were not influenced by diet, variations were only observed within time periods. Rumen $\mathrm{pH}$ decreased linearly from 7.05 to 6.13 and 7.11 to 6.37 for $\mathrm{OD}$ and $\mathrm{CD}$ respectively $(\mathrm{P}<0.05)$. Minimum $\mathrm{NH}_{3}-\mathrm{N}$ concentrations $\left(\mathrm{mg} \mathrm{dL}^{-1}\right)$ were reached 12 and $18 \mathrm{~h}$ after morning meal for OD (7.10) and CD (5.82) respectively. Rumen degradation was larger for oats than corn. Whole oats rather than corn fed up to $55 \%$ of total DM seems to improve protein deposition, without significant changes in animal performance, rumen environment or blood parameters.
\end{abstract}

Key words: Blood steers, feed efficiency, parameters, rumen environment.

\section{INTRODUCTION}

In Argentina feeding grain in intensive beef cattle rather than grass finishing operations became more usual two decades ago. Then, few enterprises grew as commercial feedlots while many others remained as a commercial segments integrated within different sized farms (Arelovich et al., 2011). Pen feeding is frequently used at different stages of growth and finishing. Although corn (Zea mays L.) is the choice to include in beef cattle diets, other grains and by-products are available in the market.

Wherever corn crop is environmentally and economically feasible, it is the most preferred energy source for growing-fattening in beef cattle intensive systems. It is well known that corn has the highest energy content (NRC, 1996) contrasted to other grains. About $80-85 \%$ processed corn grain would be included in a typical feedlot diet. Many studies showed that

${ }^{1}$ Universidad Nacional del Sur, Departamento de Agronomía (CERZOS-CIC Provincia de Buenos Aires), San Andrés 800, 8000 Bahía Blanca, Argentina.

*Corresponding author (hugoarel@ criba.edu.ar).

${ }^{2}$ Universidad Nacional del Sur, Departamento de Agronomía, San Andrés 800, 8000 Bahía Blanca, Argentina.

Received: 1 March 2013.

Accepted: 1 August 2013.

doi:10.4067/S0718-58392013000300009 grain processing leads to enhanced animal performance because of increased starch availability; diminished mycotoxin activity and improvement of mixing properties (Owens et al., 1997). However, economic returns from corn processing would vary with price, feed efficiency response, energy cost, and size of operation (Macken et al., 2006). Processing methods seems to increase in cost with processing intensity, and the feed efficiency threshold at which processing becomes profitable also increases (Macken et al., 2006).

Forage level and type of grain in the diet would also affect biological and economic response to grain processing (Owens et al., 1997; Macken et al., 2006). At moderate to high roughage levels in the diet, smaller differences in animal performance could be expected regardless of whole or processed grain or different grain sources are included. In addition, feeding whole grains in moderate to high forage diets could be of benefit for animal health as well as for beef quality.

High physically effective NDF content due to high forage proportion reduced acidosis risk by sustaining $\mathrm{pH}$ at 5.8 over a longer period of time (Yang and Beauchemin, 2009). The NDF content of a grain like whole oats (Avena sativa L.) can also contribute to a healthier rumen environment and whole animal welfare. As far as consumers concern about beef quality, differences 
between grass-fed and grain-fed cattle were addressed in many studies. A review of Daley et al. (2010) suggests that to obtain a healthier lipid profile and higher antioxidant content in cattle require finishing on $100 \%$ forage-based diets, which could influence feed efficiency, economics, and some beef attributes. When oats was supplemented as whole grain to grazing steers increased performance without significant changes in beef lipid profile was observed (Marinissen et al., 2006; 2008). Oats grain has shown some potential to substitute for corn in a $55 \%$ grain pelleted diet without significant effect on performance in young growing cattle (Arelovich et al., 2012). There is scarce information available evaluating how the inclusion of whole grains of different sources in moderate to high roughage diets may influence animal performance and beef characteristics. The objective of this study was to compare performance, beef ultrasound measurements, ruminal parameters, and blood serum profile of steers receiving moderate forage whole corn or whole oats based diets.

\section{MATERIALS AND METHODS}

The study was conducted at Departamento de Agronomía, Universidad Nacional del Sur (UNS), Bahía Blanca (384ㄴ ' S, 62 ${ }^{\circ} 10^{\prime} \mathrm{W}$ ), Argentina. Feeding conditions and facilities were intended to resemble those followed by producers of the area. Practices for animal care followed those recommended for animal well being by the Servicio Nacional de Sanidad y Calidad Agroalimentaria (SENASA, 2012).

\section{Animals and treatments}

Ten weaned Aberdeen Angus steers (203 \pm 18 kg; age 32 wk) were selected from UNS herd. Each steer was treated with $5 \mathrm{~mL}$ of ivermectin (Merial Argentina, Martínez, Provincia de Buenos Aires, Argentina) for internal and external parasites, vaccinated with $5 \mathrm{~mL}$ of polyvalent IR T (Rosenbusch, Buenos Aires, Argentina) and $5 \mathrm{~mL}$ of neumoenteritis vaccine (Laboratorio Invesbio S.R.L., Buenos Aires, Argentina). The animals were identified by means of numbered plastic tags, assigned by average weight to two groups and randomly allotted to individual pens $(3.3 \mathrm{~m} \times 5 \mathrm{~m})$. Plastic feeders and water troughs were placed in each pen.

The experimental dietary treatments were: 1) whole oats grain based diet (OD) and 2) whole corn grain based diet (CD), both formulated to reach isoprotein levels (14\% CP). The diets comprised (DM basis) $55 \%$ grain (either corn or oats), $30.1 \%$ barley (Hordeum vulgare L.) straw, $10.6 \%$ whole soybean (Glycine max [L.] Merr.) and $4.3 \%$ supplemental premix plus urea and monensin (Table 1). For diet preparation the roughage was processed with a hammer mill (Carlos Mainero and Co., Bell Ville, Córdoba, Argentina) through a $30 \mathrm{~mm}$ mesh and subsequently added to the other components of each diet
Table 1. Composition of diets based on whole corn or oats grain fed to Aberdeen Angus steers.

\begin{tabular}{lrr}
\hline & \multicolumn{2}{c}{ Dietary treatment } \\
\cline { 2 - 3 } Item & OD & CD \\
\hline Ingredient, \% & 30.05 & 30.03 \\
Barley straw & 54.96 & 54.37 \\
Whole cereal grains & 10.40 & 10.83 \\
Whole soybeans & 4.60 & 4.77 \\
UVM-Premix ${ }^{1}$ & & \\
Chemical composition ${ }^{2}$ & 88.80 & 88.90 \\
DM, \% & 14.80 & 14.00 \\
CP, \% & 45.70 & 31.80 \\
NDF, \% & 23.20 & 15.40 \\
ADF, \% & 2.31 & 2.64 \\
ME, Mcal kg & & \\
\hline
\end{tabular}

OD: diet based on whole oats grain; $\mathrm{CD}$ : diet based on whole corn grain; DM: dry matter; CP: crude protein; NDF: neutral detergent fiber; ADF: acid detergent fiber; ME: metabolizable energy.

${ }^{1}$ UVM-Premix (urea-vitamin-mineral premix). Urea was included to adjust to isoprotein levels both diets with the same proportions of corn or oats which differ in $\mathrm{CP}$ content. Wheat middling was used as a carrier for: urea, $\mathrm{CaCO}_{3}, \mathrm{NaCl}$ and a vitamin-mineral supplement. The composition of the whole premix was: $48.2 \%$ and $50.2 \%$ (wheat middling); $13.6 \%$ and $10.5 \%$ (urea); $24.2 \%$ and $25.3 \%\left(\mathrm{CaCO}_{3}\right)$; $0.20 \%$ and $0.22 \%$ (vitamin-mineral supplement). The vitamin-mineral supplement composition per kg was: vitamin A $3333330 \mathrm{IU}$; vitamin $\mathrm{D}_{3} 666666 \mathrm{IU}$; vitamin E $3.000 \mathrm{~g}$; vitamin $\mathrm{B}_{1} 0.560 \mathrm{~g}$; vitamin $\mathrm{B}_{2} 0.660 \mathrm{~g}$; nicotinic acid $1.600 \mathrm{~g} ; \mathrm{Zn} 38.330$ g; Mn 12.330 g; Fe 8.330 g; Cu 3.330 g; S 50.000 g; Mg 12.330 g; Co 160.000 mg; Se $73.000 \mathrm{mg}$; I $160.000 \mathrm{mg}$; Monensin $15000 \mathrm{~g}$.

${ }^{2}$ Analyzed values (duplicate samples) for DM, CP (AOAC, 2000), NDF, ADF (Van Soest et al., 1991). ME was estimated from tabular values of each dietary component (NRC, 1996).

in a horizontal mixer (Marion Mixer, Rapids Machinery Company, Marion, Iowa).

Treatments were assigned randomly to pens. Animals were fed twice a day at 08:00 and 17:30 h. Diets were restricted to $5 \mathrm{~kg}$ DM daily per animal during previous 13 $\mathrm{d}$ adaptation; followed by a $60 \mathrm{~d}$ experimental period in which diets were offered ad libitum.

Refusals were weighed, recorded, and discarded before feeding. Feed and refusals grab samples were collected from each pen daily composited within animal and dried at $60{ }^{\circ} \mathrm{C}$ in a forced air oven to constant weight. After drying, each sample was ground through a 2-mm screen in a Wiley mill (Standard Model 3, Arthur H. Thomas, Philadelphia, USA) and stored for later analysis.

Feed chemical determinations included crude protein $\left(\mathrm{CP}=\mathrm{g} \mathrm{N} 100 \mathrm{~g}^{-1} \mathrm{DM} \times 6.25\right)$ by macro-Kjeldahl $\mathrm{N}$ analyses (AOAC, 2000). Neutral detergent fiber (NDF), acid detergent fiber (ADF) and acid detergent lignin (ADL) were determined with an ANKOM Fiber Analyzer (Ankom Technology, Fairport, New York, USA) following the detergent system procedures (Van Soest et al., 1991), including $\alpha$-amylase but without sodium sulfite. Feed ingredient and chemical composition are reported on Table 1. Diet daily supply was managed according to the feed rejected and weighed daily, and procedures for next day allowances followed the criteria shown in Table 2, which allowed a gradual increase in daily intake.

\section{Performance, blood and ultrasound measurements}

The DM intake (DMI) was computed by subtracting dry 
Table 2. Criteria utilized for daily dietary supply to each individual feeder.

\begin{tabular}{|c|c|}
\hline Feed refusal & Feed allowance respect to previous day \\
\hline+2 & $\mathrm{~g} \mathrm{~d}^{-1}$ \\
\hline$<100$ & Increase 250 \\
\hline 100 to 250 ( 3 consecutive days) & Increase 250 \\
\hline 250 to 500 & No change \\
\hline$>500$ ( 3 consecutive days $)$ & Reduce 250 \\
\hline
\end{tabular}

orts weight from dry weight of the feed provided for each individual. Steers were weighed at $30 \mathrm{~d}$ intervals before feeding at 08:00 $\mathrm{h}$ and were not withheld from feed or water. Average daily gains (ADG) and feed to gain (F/G) ratio were computed from live weight differences and intake data. Blood samples were obtained by caudal vein venipuncture at the last day of the experiment. Serum analyses were performed for glucose, non esterified fatty acids (NEFA), total protein, $\mathrm{Ca}, \mathrm{P}, \mathrm{Mg}, \mathrm{Na}$, and $\mathrm{K}$ were determined by automated methods in a commercial lab.

At the beginning and final stage of the experimental period live animal measurements by ultrasound techniques were performed. The cattle were evaluated to determine changes in rib eye area (RA), back fat (BF) and hip fat (HF) thickness. An ultrasound scanner (Falco 100, Pie Medical Equipment, Maastricht, The Netherlands) was used to determine $12^{\text {th }}$ rib BF and RA (Longissimus dorsi muscle area) both in the same image. A second image was for fat thickness at hip, positioning the transducer between the hip and the ischium. The software BioSoft Toolbox model Pro 500 version 2.1 (Biotronics Inc., Ames, Iowa, USA) was used for image capture. The number of ultrasound observations was two per animal and parameter (RA, BF, and HF), the first at the beginning and the second at the end of the $60 \mathrm{~d}$ experimental period. Images were processed at the Centro de Interpretación de Imágenes Ecográficas (CIIE-Instituto Nacional de Tecnología Agropecuaria INTA Castelar, Argentina). The rate of tissue growth $(\Delta \mathrm{TG})$ from the end to the beginning of the experimental period for $\mathrm{RA}$ and $\mathrm{BF}$ were calculated from the differences in thickness established at for each observation in time. Dietary DM composition, DMI, individual initial body weight, body condition and breed; and available environmental temperature were introduced in the computer NRC-model (NRC, 1996) to estimate metabolizable protein (MP) as well as degradable intake protein (DIP) for each individual. These calculations were performed to contrast predicted gains with actual ADG's.

\section{Rumen parameters and in situ evaluation of grains}

To further describe experimental diets digestion, four ruminally cannulated Aberdeen Angus steers were allocated to a completely randomized design, receiving both dietary treatments following procedures described above. Then, rumen $\mathrm{pH}$ and $\mathrm{NH}_{3}-\mathrm{N}$ concentrations were determined. Rumen liquid was obtained at $0,2,4,6$, $8,12,18$, and $24 \mathrm{~h}$ after the morning meal, and filtered through four layers of cheesecloth. The $\mathrm{pH}$ of the filtrate was measured immediately before the inhibition of the microbial activity of fluid by adding $2 \mathrm{~mL}$ of a $7.2 \mathrm{~N} \mathrm{HCl}$ solution (Merchen et al., 1986). Rumen samples were immediately frozen and kept for $\mathrm{NH}_{3}-\mathrm{N}$ determination. A colorimetric procedure was used to evaluate $\mathrm{NH}_{3}-\mathrm{N}$ concentrations (Broderick and Kang, 1980) using $50 \mu \mathrm{L}$ aliquots from the ruminal samples and a spectrophotometer (Beckman DU 64, Beckman Instruments, Fullerton, California, USA).

The degradability parameters of oats and corn grains incubated in Dacron bags were also established. For this in situ study all four cannulated animals were adapted for $7 \mathrm{~d}$ to the diet; used as replicates and oats and corn were the treatments. Then $10 \times 20 \mathrm{~cm}$ Dacron bags (Ankom Technology Corporation, Fairport, New York, USA) containing only oats or corn grain were inserted at different time intervals. The same number of bags containing either corn or oats was exposed to the rumen environment for 0 , $2,4,6,8,12,24$, and $30 \mathrm{~h}$ after feeding. The bags were dried, weighed, filled with the ground substrates and sewed to a polyester cord with a metal weight attached to its extreme in order to achieve proper immersion in the ventral sac. Before insertion of bags through the rumen cannula they were soaked in water at $20^{\circ} \mathrm{C}$, and those from $0 \mathrm{~h}$ were not exposed. After extraction at the corresponding incubation times, bags were immediately rinsed under tap water and subsequently frozen to stop fermentation. Later on, bags were rinsed again in a washing machine, dried at $60{ }^{\circ} \mathrm{C}$, and re-weighed. The weight data were analyzed by a computer program to estimate degradability parameters, by fitting them into the equation EDMD $=a+[b c /(c+k)]$, where EDMD was effective DM degradability; $a$, the soluble fraction; $b$, the potentially degradable insoluble fraction and $c$, the rate of degradation of the rumen degradable fraction $b$ and $k$, the rumen fractional dilution rate (Ørskov and McDonald, 1979). The utilized rumen fractional dilution rate was $k=$ 0.05 for both grains.

\section{Statistical analyses}

The feeding trial was conducted as a completely randomized experiment and the variables were studied by ANOVA. The means were declared different when a significant F-test for treatment $(\alpha=0.05)$ was detected. For time-sequence data regression analyses were employed to test the relationships between $\mathrm{pH}$ and $\mathrm{NH}_{3}-\mathrm{N}$ across $24 \mathrm{~h}$ period. For the in situ study ANOVA was performed for degradation parameters with animals as replicates. The software InfoStat (Di Rienzo et al., 2010) was used for all data analysis.

\section{RESULTS}

Productive performance, blood and beef quality parameters

Although calculated daily ME intake tended to be higher 
for $\mathrm{CD}(\mathrm{P}=0.0887)$ compared to $\mathrm{OD}$, no differences were found for daily DM intake, ADG or F/G (Table 3). Mean live weight change followed an identical pattern across time for both experimental diets across the weighing periods, as illustrated by Figure 1 .

The average CP content of the diet resulted slightly higher for OD compared with $\mathrm{CD}$, attributable to expected deviations generated by manipulation of the ingredients in the mixing process (Table 1). However due to slight numeric differences in total DM intake, total protein intake resulted non significant, averaging 945 and $921 \mathrm{~g}$ $\mathrm{d}^{-1}$ for OD and CD, respectively. Nevertheless, significant differences $(\mathrm{P}<0.01)$ between both treatments in MP and DIP intake (Table 3 ) were predicted from the differences in protein degradability arising from tabular values for corn and oats grains (NRC, 1996). Thus expected MP intake was $19.4 \%$ larger and DIP $43.3 \%$ smaller for CD compared with OD.

Blood concentration of $\mathrm{Mg}$ was higher in those animals receiving the $\mathrm{OD} \operatorname{diet}(\mathrm{P}=0.0564)$. All other blood parameters measured were not affected by experimental diets (Table 4).

Initial, final, and $\Delta \mathrm{TG}$ data for RA and BF thickness

Table 3. Daily nutrient intake, performance and predicted intake values for steers fed diets based on whole grain oats or corn.

\begin{tabular}{|c|c|c|c|c|}
\hline \multirow[b]{2}{*}{ Item } & \multicolumn{2}{|c|}{ Dietary treatment } & \multirow[b]{2}{*}{ SEM } & \multirow[b]{2}{*}{ P-value } \\
\hline & OD & $\mathrm{CD}$ & & \\
\hline \multicolumn{5}{|l|}{ Intake } \\
\hline $\mathrm{DM}, \mathrm{kg}$ & 6.39 & 6.58 & 0.13 & 0.5096 \\
\hline $\mathrm{CP}, \mathrm{g}$ & 946 & 921 & 19.20 & 0.5474 \\
\hline $\mathrm{ADG}, \mathrm{kg}$ & 1.18 & 1.19 & 0.05 & 0.9155 \\
\hline $\mathrm{F} / \mathrm{G}$ ratio, $\mathrm{kg} \mathrm{kg}^{-1}$ & 5.48 & 5.64 & 0.24 & 0.7618 \\
\hline \multicolumn{5}{|l|}{ Predicted values ${ }^{1}$} \\
\hline ME, Mcal & 14.76 & 17.10 & 0.50 & 0.0073 \\
\hline MP, g & 486 & 602 & 20.40 & $<0.0001$ \\
\hline DIP, g & 700 & 541 & 21.60 & 0.0005 \\
\hline DIP balance, $\mathrm{g}$ & 169 & -75 & 40.80 & $<0.0001$ \\
\hline
\end{tabular}

${ }^{1}$ Calculated from the NRC (1996) model.

OD: diet based on whole oats grain; CD: diet based on whole corn grain; SEM: standard error of the mean; DM: dry matter; CP: crude protein; ADG: average daily gain; F/G: feed to gain ratio; ME: metabolizable energy; MP: metabolizable protein; DIP: degradable intake protein.

Within a row, means differ when $\mathrm{p}<0.05$.

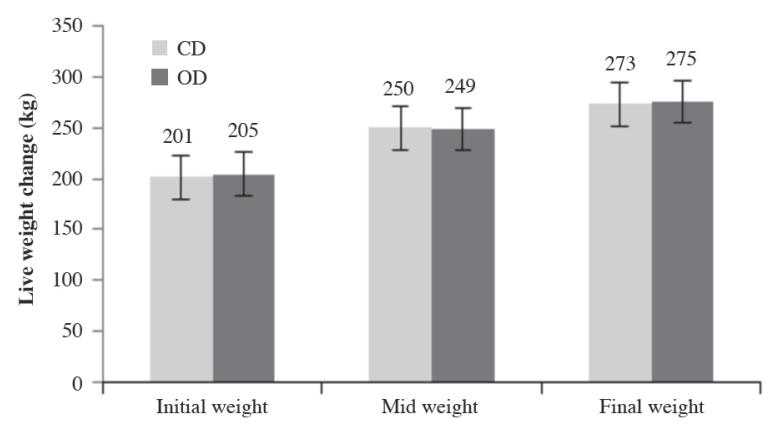

OD: diet based on whole oats grain; CD: diet based on whole corn grain.

Figure 1. Live weight change of steers fed diets based on whole grain oats (OD) or corn (CD). are reported in Table 5. Differences between treatments were apparent only for $\Delta \mathrm{TG}$ in RA, which was $40 \%$ greater on a daily basis for animals receiving OD than those on the $\mathrm{CD}$ diet. Conversely, a larger trend $(\mathrm{P}=$ 0.0787) for $\mathrm{BF}$ deposition was found for $\mathrm{CD}$ compared to OD treatment. Observed HF values resulted almost identical at the beginning as well as at the end for both treatments averaging 1.46 and $2.77 \mathrm{~mm}$, respectively.

\section{Rumen parameters and DM degradability of grains}

The rumen $\mathrm{pH}$ for both diets decreased linearly after the first daily meal following a similar pattern, as shown by the regression in Figure $2 \mathrm{a}$ where $\mathrm{R}^{2}=0.377$ and 0.874 for $\mathrm{OD}$ and $\mathrm{CD}$ respectively $(\mathrm{P} \leq 0.05)$. Neither treatment effect nor interaction treatment by sampling hour was found. The $\mathrm{pH}$ values ranged from 7.05 to 6.13 and 7.11 to 6.37 for $\mathrm{OD}$ and $\mathrm{CD}$, respectively, within the $24 \mathrm{~h}$ interval. As shown in Figure $2 \mathrm{~b}$ rumen $\mathrm{NH}_{3}-\mathrm{N}$ changed with sampling time. It was described by a quadratic regression for both diets where $\mathrm{R}^{2}$ was 0.6718 and 0.7912 for $\mathrm{OD}$ and $\mathrm{CD}$, respectively $(\mathrm{P}>0.05)$. Treatment had no effect on rumen $\mathrm{NH}_{3}-\mathrm{N}$; however, concentration varied with sampling hour as expected. Thus, minimum $\mathrm{NH}_{3}-\mathrm{N}$ concentrations were reached 12 and $18 \mathrm{~h}$ after morning meal for OD $\left(7.10 \mathrm{mg} \mathrm{dL}^{-1}\right)$ and $\mathrm{CD}\left(5.82 \mathrm{mg} \mathrm{dL}^{-1}\right)$ respectively.

In Table 6 are reported the degradation constants as well as values for DMED for oats and corn grains, as main components of the experimental diets. Thus, oats showed

Table 4. Blood parameters in steers fed diets based on whole grain oats or corn.

\begin{tabular}{|c|c|c|c|c|}
\hline \multirow[b]{2}{*}{ Item } & \multicolumn{2}{|c|}{ Dietary treatment } & \multirow[b]{2}{*}{ SEM } & \multirow[b]{2}{*}{$\mathrm{P}$-value } \\
\hline & OD & $\mathrm{CD}$ & & \\
\hline Glucose, $\mathrm{g} \mathrm{L}^{-1}$ & 0.86 & 0.85 & 0.02 & 0.9065 \\
\hline NEFA, mEq L ${ }^{-1}$ & 0.38 & 0.38 & 0.01 & 0.7834 \\
\hline Total protein, $\mathrm{g} \mathrm{dL}^{-1}$ & 6.85 & 7.06 & 0.08 & 0.1755 \\
\hline $\mathrm{Ca}, \mathrm{mg} \mathrm{dL}^{-1}$ & 9.72 & 10.44 & 0.23 & 0.1152 \\
\hline $\mathrm{P}, \mathrm{mg} \mathrm{dL}^{-1}$ & 9.12 & 9.64 & 0.50 & 0.6292 \\
\hline $\mathrm{Mg}, \mathrm{mg} \mathrm{dL}^{-1}$ & 1.60 & 1.36 & 0.06 & 0.0564 \\
\hline $\mathrm{Na}, \mathrm{mEq} \mathrm{L}^{-1}$ & 137.80 & 137.80 & 0.36 & 0.9999 \\
\hline $\mathrm{K}, \mathrm{mEq} \mathrm{L}^{-1}$ & 5.16 & 4.88 & 0.16 & 0.4127 \\
\hline
\end{tabular}

OD: diet based on whole oats grain; CD: diet based on whole corn grain; SEM standard error of the mean; NEFA: non-esterified fatty acids.

Table 5. Live animal ultrasound measurements of the carcass of steers receiving diets based on whole grain oats or corn.

\begin{tabular}{|c|c|c|c|c|c|c|}
\hline \multirow[b]{2}{*}{ Item } & \multicolumn{2}{|c|}{ Initial $^{1}$} & \multicolumn{2}{|c|}{ Final $^{2}$} & \multicolumn{2}{|c|}{$\Delta \mathrm{TG}^{3}$} \\
\hline & RA & $\mathrm{BF}$ & RA & $\mathrm{BF}$ & RA & $\mathrm{BF}$ \\
\hline & $\mathrm{cm}^{2}$ & $\mathrm{~mm}$ & $\mathrm{~cm}^{2}$ & $\mathrm{~mm}$ & $\mathrm{~cm}^{2} \mathrm{~d}^{-1}$ & $\mathrm{~mm} \mathrm{~d}^{-1}$ \\
\hline \multicolumn{7}{|c|}{ Dietary treatment } \\
\hline OD & 33.30 & 1.12 & 42.02 & 1.58 & 0.15 & 0.01 \\
\hline $\mathrm{CD}$ & 34.54 & 1.06 & 39.72 & 2.54 & 0.09 & 0.03 \\
\hline SEM & 1.02 & 0.05 & 1.47 & 0.28 & 0.02 & 0.01 \\
\hline P-value & 0.5731 & 0.5447 & 0.4673 & 0.0787 & 0.0316 & 0.0729 \\
\hline
\end{tabular}

OD: diet based on whole oats grain; CD: diet based on whole corn grain; SEM: standard error of the mean.

${ }^{1}$ Measurements at the beginning of the experiment: RA: rib eye area; BF: back fat depth at $12^{\text {th }}$ rib.

${ }^{2} \mathrm{RA}$ and $\mathrm{BF}$ measurements made at the end of the experiment.

${ }^{3} \Delta \mathrm{TG}$ : rate of daily growth for RA and $\mathrm{BF}$ in a $60 \mathrm{~d}$ period. 
a larger soluble fraction $a$ with a mean value of $69.14 \%$ and a smaller potential degradable fraction $b$ with a mean value of $30.83 \%$. Instead corn grain exhibited a smaller $a$ and larger $b$ fractions with mean values of $19.83 \%$ and $79.81 \%$, respectively. The rate of degradation $c$ for fraction $b$ resulted 4.5 times larger for corn than oats $(\mathrm{P}<$ $0.05)$. No differences were detected for DMED.

\section{DISCUSSION}

\section{Animal performance}

Distinctive animal response, feed efficiency and carcass
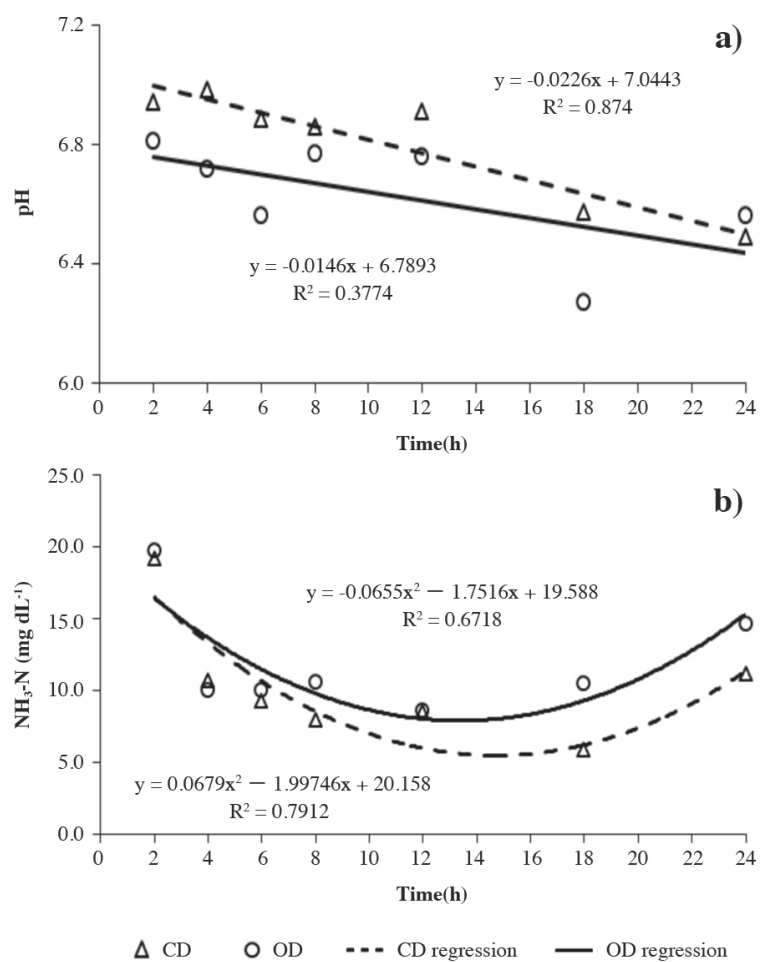

${ }^{1} \mathrm{pH}$ regression: P values were 0.0029 and 0.0500 , and means 6.8 and 6.6 for $\mathrm{CD}$ and $\mathrm{OD}$, respectively.

${ }^{2} \mathrm{NH}_{3}-\mathrm{N}$ regression: $\mathrm{P}$ values were 0.3979 and 0.4033 , and means 10.3 and $12.0 \mathrm{mg} \mathrm{dL}^{-1}$ for $\mathrm{CD}$ and $\mathrm{OD}$, respectively.

Figure 2. Regressions for (a) rumen $\mathrm{pH}$ (linear) ${ }^{1}$ and (b) $\mathrm{NH}_{3}-\mathrm{N}$ concentration (quadratic) ${ }^{2}$ at different time intervals in ruminally cannulated animals receiving OD or CD.

Table 6. In situ degradation parameters, effective and potential degradability of energy feed components of experimental diets CD and OD ${ }^{1}$.

\begin{tabular}{|c|c|c|c|c|}
\hline \multirow[b]{2}{*}{ Item } & \multicolumn{2}{|c|}{ Substrate } & \multirow[b]{2}{*}{ SEM } & \multirow[b]{2}{*}{ P-value } \\
\hline & Oats & Corn & & \\
\hline \multicolumn{5}{|c|}{ Degradability parameters ${ }^{1}$} \\
\hline$a, \%$ & 69.14 & 19.83 & 9.34 & 0.0010 \\
\hline$b, \%$ & 30.83 & 79.81 & 9.28 & 0.0016 \\
\hline$c, \% / \mathrm{h}$ & 0.02 & 0.09 & 0.01 & 0.0222 \\
\hline DMED, $\%$ & 77.06 & 71.35 & 1.42 & 0.1636 \\
\hline
\end{tabular}

CD: based on whole corn grain; OD: based on whole oats grain; SEM: standard error of the mean.

${ }^{1} a, b, c$ are constants in the equation DMED: dry matter effective degradability $=a$ $+[b c /(c+k)]$, where $a=$ the rapidly soluble fraction, $b=$ the potentially degradable fraction, $c=$ the rate of degradation of fraction $b$. Fractional dilution rate $(k)=0.05$. characteristics could be expected from different grain sources added to the ration. Furthermore grain processing and inclusion level of other dietary components could interact affecting in different ways these parameters (Mathison, 1996; Owens et al., 1997; Corrigan et al., 2007).

Calculated ME and MP daily intake was higher for CD than OD, being DIP values high for OD but exhibited a negative balance for $\mathrm{CD}$. Therefore, differences in animal performance arising from these diets should have been expected. In fact when required inputs for each individual, as described in Materials and Methods, were inserted in the NRC computer model (NRC, 1996), calculated MP would support ADG's of 1.09 and $1.55 \mathrm{~kg}$ animal $^{-1}$, but the ME supply would limit them to 0.97 and $1.35 \mathrm{~kg}$ animal $^{-1}$ for OD and CD, respectively. However, the observed mean ADG values resulted almost identical: 1.18 and $1.19 \mathrm{~kg}$ animal ${ }^{-1} \mathrm{~d}^{-1}$, for both diets. The accuracy of NRC model (NRC, 1996) to predict ADG could be affected by different aspects. Prediction discrepancies with actual data were found particularly at low rates of gain, biases could appear by estimating NE content from TND related to nutrient composition and different feed sources among others (Block et al., 2006). However, for the purposes of this study the NRC program was considered a suitable standard to contrast with observed ADG data, particularly to establish potential differences between corn and oats grains. In this study, the moderate level of unprocessed grain inclusion in the diet, high NDF content and DIP availability could have been involved in reducing the nutritional gap and consequently productive performance between oats and corn based diets.

Besides, a faster rumen degradation rate and extent of starch from oats compared with corn (Ørskov, 1986; Owens et al., 1997) are in agreement with the findings of this study. Since the largest portion of the DM is starch in both grains (NRC, 1996; Huntington, 1997), then DM degradability could be expected to resemble starch degradation. Even more, oats starch degrades faster than the other DM components (Cerneau and MichaletDoreau, 1991). The synchronous supply of carbohydrate and protein could benefit efficiency of nutrient utilization. The faster ruminal degradation rate for oats would provide available carbohydrates to increase protein synthesis for the largest DIP supply in OD, compared to the negative DIP balance for CD. A synchronous diet could improve microbial protein synthesis and VFA production, utilization of recycled $\mathrm{N}$, and decrease $\mathrm{N}$ output which would benefit animal performance and decrease environmental impact (Cole and Todd, 2008; Seo et al., 2010). Conversely, the comparatively higher $\mathrm{ME}$ associated to a negative DIP balance for CD was probably limiting NDF rumen digestion in this diet. DIP balance becomes more critical with high dietary NDF.

Waldo (1973) suggested that rumen fermentation of starch is $94 \%$ and $74 \%$ for oats and corn respectively. Then 
higher starch escape to duodenum would be expected from corn but it minimizes with the inclusion of $40 \%$ to $60 \%$ corn in the diet. The substitution of corn for oats up to $40 \%$ of total diet with cattle of similar initial weight did not show significant changes in rumen fermentation or effective nutrient utilization (Dutta and Thakur, 1992). For 54\% inclusion of dry processed corn, oats, wheat or barley grains the ADG ranged from 1.09 to $1.17 \mathrm{~kg} \mathrm{~d}^{-1}$, with no differences for ADG or $\mathrm{F} / \mathrm{G}$ ratio between oats and corn (Dion and Seoane, 1992). Although grain was processed rather than whole, ADG resulted similar to the observed values in this study. When a $60 \%$ oats or corn pelleted diet was fed to similar weight steers as in this study, again no differences in F/G were found, but ADG was higher for corn, being $1.23 \mathrm{vs} .1 .41 \mathrm{~kg}$ animal $^{-1}$ daily for oats and corn based diets respectively (Arelovich et al., 2012).

Inter and intra-species variability in grain composition and degradation is other aspect that many times is overlooked when considering grain nutritional value and animal response. An important variability among various oats genotypes was found by Martínez et al. (2010). Waldo (1973) reported cultivar variability in starch escape for different corn grains. For distinct fractions of the grain, differences detected within exceeded those between species for cultivars of oats and corn (Micek and Kowalski, 2010).

\section{Blood profile and rumen parameters}

All blood data except NEFA were contrasted with reference values as suggested by Boyd (1985). Total protein, $\mathrm{Ca}, \mathrm{Na}$, and $\mathrm{K}$ were within normal ranges for blood serum. Glucose values resulted identical across treatments but somewhat higher than reference values (0.42-0.75 $\left.\mathrm{g} \mathrm{L}^{-1}\right)$. Glycogenic stimuli can be induced by a larger propionate production (Raun et al., 1976; Cinar and Sulu, 1995) expected from grain feeding. Since monensin was included in both diets, which in turn modify fermentation favoring propionate production, increased blood glucose could also be expected with monensin supply (Debasis and Singh, 2002; Broderick, 2004). A shift of starch digestion to duodenum from where it is absorbed as glucose (Haimoud et al., 1995) could also be a factor increasing glucose level. The last would be occurring particularly with $\mathrm{CD}$ because of the comparatively lower starch degradation of corn grain, as discussed above.

NEFA concentrations can be used as a measure of adequate energy intake (Rudik et al., 2004), and low NEFA values are found in the blood of healthy animals with positive energy balance. Meanwhile high concentrations (> $40 \mathrm{mEq} \mathrm{L}^{-1}$ ) indicate adipose tissue lipolysis, which occurs in response to increased energy demand.

The average $\mathrm{P}$ concentration in blood is over the reference interval (4.3-7.8 $\mathrm{mg} \mathrm{dL}^{-1}$ ) with no treatment effect. Erickson et al. (2002) found values of $8.0 \mathrm{mg} \mathrm{dL}^{-1}$ with different levels of $\mathrm{P}$ in the diet $(0.22 \%, 0.28 \%$, and $0.24 \%$ ) for feedlot steers, but levels changed significantly over time. The increased blood $\mathrm{Mg}$ for OD ( $\mathrm{p}=0.0564)$ could be attributed to the much larger content of $\mathrm{Mg}$ in oats $(0.42 \%)$ than in corn $(0.11 \%)$ as reported by NRC (1996). Reference values range from 1.7 to $3.0 \mathrm{mg} \mathrm{dL}^{-1}$, thus, animals with blood values of $1.36 \mathrm{mg} \mathrm{dL}^{-1}$ in $\mathrm{CD}$ could be considered as marginal in $\mathrm{Mg}$. Thus, $\mathrm{Mg}$ availability in CD could have diminished efficiency of energy utilization, mainly because the role of $\mathrm{Mg}$ as required cofactor in glycolysis regulation, which might have been an additional negative aspect contributing on overall performance for animals receiving CD.

The pre and postprandial variations in $\mathrm{pH}$ and $\mathrm{NH}_{3}-\mathrm{N}$ traits were affected by the time of the day. A significant linear decrease was observed for rumen $\mathrm{pH}$ with both diets; however, the mean values were over 6.5 along the $24 \mathrm{~h}$ period. Since subacute acidosis was defined for a rumen $\mathrm{pH}<5.6$ for more than $12 \mathrm{~h}$ (Owens et al., 1998), there was no risk of rumen acidosis. Besides, sustaining $\mathrm{pH}>6.0$ is critical for efficiency of microbial attachment and fiber digestion in the rumen (Sung et al., 2007).

Orskov (1986) indicated that depression in fiber digestion from feeding cereal grains can be obviated by reducing the extent that cereal grains are processed. So feeding both grains in the whole form and the high amount of effective NDF from forage in the diet would contribute to a ruminal $\mathrm{pH}$ sufficiently high to maintain fiber digestion and avoid acidosis.

The ruminal $\mathrm{NH}_{3}-\mathrm{N}$ concentration followed a typical pattern with a quadratic response to time; it was highest $2 \mathrm{~h}$ after the meal, then gradually decreased to reach a minimum between 12 and $14 \mathrm{~h}$ later, after, which it rose up again to their pre-feeding level for both diets. This is a typical pattern for ruminal $\mathrm{NH}_{3}-\mathrm{N}$ rumen pool. It fits the model which usually peaks after feeding followed by a decrease in $\mathrm{NH}_{3}-\mathrm{N}$ and $\mathrm{pH}$, increase in ruminal VFA and $\mathrm{CO}_{2}$ associated with starch fermentation, accompanied by a decrease in $\mathrm{NH}_{3}$ absorption and a later increase in urea transfer across the ruminal wall (Rémond et al., 2002; Abdoun et al., 2006). The consistently lower $\mathrm{NH}_{3}-\mathrm{N}$ concentration $2 \mathrm{~h}$ after feeding can be linked to the negative DIP balance for CD. A universal constant of $5 \mathrm{mg} \mathrm{dL}^{-1}$ for $\mathrm{NH}_{3}-\mathrm{N}$ (Satter and Slyter, 1974) determined in vitro is widely accepted as the minimum concentration at which maximum microbial growth and activity would take place. However optimal concentrations of 17 to $25 \mathrm{mg} \mathrm{dL}^{-1}$ for several in vivo and in situ studies were suggested as reviewed by Kertz (2010). The average $\mathrm{NH}_{3}-\mathrm{N}$ was over $5 \mathrm{mg} \mathrm{dL}{ }^{-1}$ most of time for both diets with OD much closer to the highest suggested levels.

Degradability constants $a, b$, and $c$ could be considered typical for oats and corn grains, showing a rapid faster rumen availability from the oats in OD compared to corn grain in CD. The DM degradation pattern for corn closely resembles starch rumen degradation. A study 
from Philippeau et al. (1999) showed that corn DM degradation parameters and effective degradability were linked to starch degradation, with $98 \%$ of the variation in the extent of starch degradability accounting for that of DM degradability. Less data are available for oats grain. Oats rumen degradability was reported to be $87 \%$ and 98\% for DM and starch respectively (Herrera-Saldana et al., 1990). Because of the greater fiber content in oats than corn grain, degradation patterns might be expected to be different between starch and non starch components. This is illustrated by the differences observed among degradation parameters. However, DMED of both grains remain statistically unchanged. Large differences could exist in the proportion of nutritional fractions of oats grain (Martínez et al., 2010) that may affect their relative ruminal availability.

\section{Ultrasound measurements}

Live ultrasound is an adequate option to predict carcass composition before slaughtering (May et al., 2000). The differences found in ultrasound measurements for the rate of growth in RA and $\mathrm{BF}$ between $\mathrm{CD}$ and $\mathrm{OD}$ are remarkable. While $\mathrm{BF}$ is an important commercial trait, the RA is mostly healthy lean beef. Published data contrasting carcass characteristics between oats and corn based rations was not found. Oats grain supplementation on pasture increased RA in a recent study (Ferradás et al., 2012). Processing of oats (whole vs. ground grain) failed to change RA, or dressing percentage, or animal performance (Rojas et al., 2011). The DIP balance and energy availability should have favored a greater microbial protein synthesis in the rumen for OD, thus the microbial protein outflux should promote a larger amino acid availability at the duodenum. This may explain to some extent the differences in fat and protein deposition between both diets.

\section{CONCLUSIONS}

Our results indicate that total mixed rations based on either corn or oats fed up to $55 \%$ of total DM to growing animals do not change blood profile or modify rumen environment. Moreover, compared with whole corn, whole oats increased rate of protein deposition as measured by ultrasound RA with no negative impact on animal performance. Under the conditions of our experiment whole oats appeared to substitute equally for whole corn. As additional implications, these results may be useful for small producers that harvest their own grain, particularly in areas where corn production is limited by environmental conditions. Other considerations such as higher cost of corn than oats, regional availability and transportation add to the potential benefits of feeding oats as a substitute for corn on animal performance and beef quality, which deserves further research. Tabular nutritional values of oats and corn are useful practical guide in many situations. However, animal performance cannot always be satisfactorily predicted from these values. When whole grains are supplied with an inclusion level of $50 \%$ to $60 \%$ of total diet for both grains, then animal performance seems to get closer than expected.

\section{ACKNOWLEDGEMENTS}

We wish to extend our sincere gratitude to the following students of Departamento de Agronomía, Universidad Nacional del Sur: Ana Julia Pérez Moreno, Maximiliano Sabattini, and Eugenia A. Semper for their fundamental collaboration in conducting this study. We also want to acknowledge the financial assistance of Universidad Nacional del Sur and Comisión de Investigaciones Científicas (CIC) de la Provincia de Buenos Aires.

\section{LITERATURE CITED}

Abdoun, K., F. Stumpff, and H. Martens. 2006. Ammonia and urea transport across the rumen epithelium: a review. Animal Health Research Reviews 7:43-59.

AOAC. 2000. Official methods of analysis. $17^{\text {th }}$ ed. Association of Official Analytical Chemists, Washington, DC, USA.

Arelovich,H.M., R.D. Bravo, and M.F. Martínez. 2011. Development, characteristics, and trends for beef cattle production in Argentina. Animal Frontiers 1:37-45.

Arelovich, H.M., R.D. Bravo, M.F. Martínez, y M.I. Amela. 2012. Recría de bovinos de carne con dietas basadas en granos de maíz o avena pelletizados. Revista Argentina de Producción Animal 32:125-134.

Block, H.C., T.J. Klopfenstein, and G.E. Erickson. 2006. Evaluation of average daily gain prediction by level one of the 1996 National Research Council beef model and development of net energy adjusters. Journal of Animal Science 84:866-876.

Boyd, J.W. 1985. The interpretation of serum biochemistry test results in domestic animals. Veterinary Clinical Pathology 13:714.

Broderick, G.A. 2004. Effect of low level monensin supplementation on the production of dairy cows fed alfalfa silage. Journal of Dairy Science 87:359-368.

Broderick, G.A., and J.H. Kang. 1980. Automated simultaneous determination of ammonia and total amino acids in ruminal fluid and in vitro media. Journal of Dairy Science 63:64-75.

Cerneau, P., and B. Michalet-Doreau. 1991. In situ starch degradation of different feeds in the rumen. Reproduction Nutrition Development 31:65-72.

Cinar, A., and N. Sulu. 1995. The effects of monensin on growth and development in calves. Twik Veterinerlik Ve Hay Vaneilik Dergisi 19:381-389.

Cole, N.A., and R.W. Todd. 2008. Opportunities to enhance performance and efficiency through nutrient synchrony in concentrate-fed ruminants. Journal of Animal Science 86 (E. Suppl.):E318-E333.

Corrigan, M.E., G.E. Erickson, T.J. Klopfenstein, K.J. Vander Pol, M.A. Greenquist, and M.K. Luebbe. 2007. Effect of corn processing and wet distillers grains inclusion level in finishing diets. Nebraska Beef Cattle Reports 67:33-35.

Daley, C.A., A. Abbott, P.S. Doyle, G.A. Nader, and S. Larson. 2010. A review of fatty acid profiles and antioxidant content in grass-fed and grain-fed beef. Nutrition Journal 9:1-12.

Debasis, D., and G.P. Singh. 2002. The effect of monensin enriched urea molasses mineral block on feed intake, nutrient digestibility and blood glucose in cattle fed on wheat straw based diet. AsianAustralasian Journal of Animal Sciences 15:1579-1584. 
Di Rienzo, J.A., F. Casanoves, M.G. Balzarini, L. Gonzalez, M. Tablada, y C.W. Robledo. 2010. InfoStat, Grupo InfoStat, Facultad de Ciencias Agropecuarias, Universidad Nacional de Córdoba, Argentina, Córdoba, Argentina.

Dion, S., and J.R. Seoane. 1992. Nutritive value of corn, barley, wheat and oats fed with medium quality hay to fattening steers. Canadian Journal of Animal Science 72:367-373.

Dutta, T.K., and S.S. Thakur. 1992. Effect of feeding barley, maize or oat grains in concentrate on rumen fermentation and nutrient utilization in crossbred cattle. Indian Journal of Animal Science 62:1203-1208.

Erickson, G.E., T.J. Klopfenstein, C.T. Milton, D. Brink, M.W. Orth, and K.M. Whittet. 2002. Phosphorus requirement of finishing feedlot calves. Journal of Animal Science 80:1690-1695.

Ferradás, A.M., J. Marinissen, C.P. Angelicchio, M.F. Martínez, y M. Menghini. 2012. Efecto de la suplementación con grano de avena (Avena sativa) sobre la productividad animal y calidad de la res. Revista Argentina de Producción Animal 32(Supl. 1):121-205.

Haimoud, D.A., M. Vernay, C. Bayourthe, and R. Moncoulon. 1995. Avoparcin and monensin effects on the digestion of nutrients in dairy cows fed a mixed diet. Canadian Journal of Animal Science 74:379-385.

Herrera-Saldana, R.E., J.T. Huber, and M.H. Poore. 1990. Dry matter, crude protein, and starch degradability of five cereal grains. Journal of Dairy Science 73:2386-2393.

Huntington, G.B. 1997. Starch utilization by ruminants: from basics to the bunk. Journal of Animal Science 75:852-867.

Kertz,A.F. 2010. Urea feeding to dairy cattle: a historical perspective. Professional Animal Scientist 26:257-272.

Macken, C.N., G.E. Erickson, and T.J. Klopfenstein. 2006. The cost of corn processing for finishing cattle. Professional Animal Scientist 22:23-32.

Marinissen, J., H.M. Arelovich, y M.F. Martínez. 2008. Componentes lipídicos de la carne de novillitos Aberdeen Angus en pastoreo de verdeo de avena suplementado con grano de avena entero. Revista Argentina de Producción Animal 28 (Sup. 1):41-42.

Marinissen, J., H.M. Arelovich, M.F. Martínez, y D. Ombrosi. 2006. Composición lipídica de la carne en novillitos a pastoreo sobre avena (Avena sativa) suplementados con grano de avena. Revista Argentina de Producción Animal 26(Supl. 1):43-44.

Martínez, M.F., H.M. Arelovich, and L.N. Wehrhahne. 2010. Grain yield, nutrient content and lipid profile of oat genotypes grown in a semiarid environment. Field Crop Research 116:92-100.

Mathison, G.W. 1996. Effects of processing on the utilization of grain by cattle. Animal Feed Science and Technology 58:113-125.

May, S.G., W.L. Mies, J.W. Edwards, J.J. Harris, J.B. Morgan, R.P. Garrett, et al. 2000. Using live estimates and ultrasound measurements to predict beef carcass cutability. Journal of Animal Science 78:1255-1261.

Merchen, N.R., J.L. Firkins, and L.L. Berger. 1986. Effect of intake and forage level on ruminal turnover rates, bacterial protein synthesis and duodenal amino acid flows in sheep. Journal of Animal Science 62:216-225.

Micek, P., and Z.M. Kowalski. 2010. Cereal cultivar affects protein and starch digestion of grains in different parts of gastrointestinal tract of ruminants. p. 563-564. In Crovetto, G.M.D. (ed.) 3rd EAAP International Symposium on Energy and Protein Metabolism and Nutrition, Parma, Italy. 6-10 September. Wageningen Academic Publishers, Wageningen, Netherlands.
NRC. 1996. Nutrient requirements of beef cattle. $7^{\text {th }}$ ed. National Academy Press, Washington, DC, USA.

Ørskov, E.R. 1986. Starch digestion and utilization in ruminants. Journal of Animal Science 63:1624-1633.

Ørskov, E.R., and Y. McDonald. 1979. The estimation of protein degradability in the rumen from determining the digestibility of feeds in the rumen. Journal Agricultural Science 92:499-503.

Owens, F.N., D.S. Secrist, W.J. Hill, and D.R. Gill. 1997. The effect of grain source and grain processing on performance of feedlot cattle: A review. Journal of Animal Science 75:868-879.

Owens, F.N., D.S. Secrist, W.J. Hill, and D.R. Gill. 1998. Acidosis in cattle: A review. Journal of Animal Science 76:275-286.

Philippeau, C., F. Le Deschault de Monredon, and B. MichaletDoreau. 1999. Relationship between ruminal starch degradation and the physical characteristics of corn grain. Journal of Animal Science 77:238-243.

Raun, A.P., C.O. Cooley, E.L. Potter, R.P. Rathmacher, and L.F. Richardson. 1976. Effect of monensin and feed efficiency of feedlot cattle. Journal of Animal Science 43:670-677.

Rémond, D., P. Nozière, and C. Poncet. 2002. Effect of time of starch supply to the rumen on the dynamics of urea and ammonia net flux across the rumen wall of sheep. Animal Research 5:3-13.

Rojas, G.C., S.A. Catrileo, and V.T. Grez. 2011. Productive and economic evaluation of the inclusion of whole grain oat (Avena sativa $\mathrm{L}$.) and lupin (Lupinus angustifolius $\mathrm{L}$.) in winter fattening rations for heifers. Agro-Ciencia 27:41-48.

Rudik, M.I., C.L. Buckley, and R.H. Poppenga. 2004. Detection of nonesterified (free) fatty acids in bovine serum: comparative evaluation of two methods. Journal of Veterinary Diagnostic Investigation 16:139-144.

Satter, L.D., and L.L. Slyter. 1974. Effect of ammonia concentration on rumen microbial protein production in vitro. British Journal of Nutrition 32:199-208.

SENASA. 2012. Manual de buenas prácticas en producción bovina. Servicio Nacional de Sanidad y Calidad Agroalimentaria (SENASA), Buenos Aires, Argentina. Available at http://www. senasa.gov.ar/Archivos/File/File1598-buena-practiaprod-bovina. pdf (accessed 20 November 2012).

Seo, J.K., J. Yang, H.J. Kim, S.D. Upadhaya, W.M. Cho, and J.K. Ha. 2010. Effects of synchronization of carbohydrate and protein supply on ruminal fermentation, nitrogen metabolism and microbial protein synthesis in Holstein steers. Asian-Australasian Journal of Animal Sciences 23:1455-1461.

Sung, H.G., Y. Kobayashi, J. Chang, A. Ha, I.H. Hwang, and J.K. Ha 2007. Low ruminal $\mathrm{pH}$ reduces dietary fiber digestion via reduced microbial attachment. Asian-Australasian Journal of Animal Sciences 20:200-207.

Van Soest, P.J., J.B. Robertson, and B.A. Lewis. 1991. Methods for dietary fiber, neutral detergent fiber, and nonstarch polysaccharides in relation to animal nutrition. Journal of Dairy Science 74:35833597.

Waldo, D.R. 1973. Extent and partition of cereal grain starch digestion in ruminants. Journal of Animal Science 37:1062-1074.

Yang, W.Z., and K.A. Beauchemin. 2009. Increasing physically effective fiber content of dairy cow diets through forage proportion versus forage chop length: chewing and ruminal $\mathrm{pH}$. Journal of Dairy Science 92:1603-1615. 